\title{
Rock Tumblers
}

by Watson Crossley, Grandview, Man.

The question is often asked by those viewing a display of polished rocks, "Where will we find such stones, and how will we know which ones are suitable for polishing?"

Those of us living on the prairies are somewhat limited as to the specimens available, especially in regards to specimens of so-called gem quality. Much of the material that is to be found will come from the glacial drift, and will be a cross section of the various types of rocks over which the glaciers have moved. Gravel beds and stream beds are always likely places to look over. There are usually a few specimens worth picking up, and there is always the chance that something really interesting will be found there.

During the summer, many of us may have had the pleasure of a trip to some lake shore, and probably have been attracted by the bright colors of many of the moist, waterwashed pebbles along the shores. Probably you returned home from such a trip with a quantity of these pebbles, selected either by yourself or by the young folks. The next question, what to do with them? They do not look nearly as attractive now that they are dried off, as they did on the wet lake shore. Some may go into the fish bowl, where the colors show up once more, but the majority of them just "accumulate."

Have you ever considered putting them through a rock tumbling machine? More and more people are doing just that, and are finding the resulting polished stones quite attractive and most interesting. True, the majority of these pebbles are of too "soft" a material to take a brilliant polish, nevertheless they are greatly improved.

For the person who is getting interested in the polishing of rocks, the tumbler is probably the least costly and the easiest start. Tumbling equipment can be purchased from the lapidary supply houses, such as Smith's Prairie Book Shop, 2222 Wallace Street, Regina. There are various designs of these machines, many of which are quite simple in construction, so that a person handy around a work shop can easily make his own equipment, that will do a quite satisfactory job of polishing. Briefly, a tumbler is usually a metal drum with tight ends that can be laid upon its side and revolved at from 15 to 25 revolutions per minute.

If possible, a person contemplating having a tumbler made should see one or more in operation before attempting the job. It would also be worth while subscribing to a lapidary publication, of which there are several, or securing a book on the subject. These also are available through the lapidary supply houses. Many valuable suggestions can be gleaned from the pages of such publications.

The tumbling process is not a "doit-over-night" job. As in all phases of the lapidary hobby, there are a number of procedures and polishing agents which may do an equally good job of polishing. However, I have found that it will take about a month's continuous operation of the tumbler to complete a batch of rocks.

The following procedure may be expected to give fair results, as a start, and may be altered as experience is gained. First week-use a coarse silicone carbide grinding grit, of say 100 coarseness, then wash the stones and barrel thoroughly. For the second week use a finer grit, of 220 coarseness. Again wash the stones and container. It is important that no grit be carried over from one process to the next if a good job is to result. The final two weeks are the polishing period, and here various polishing agents apparently may be used, with somewhat equal results. Personally, I have depended largely upon the detergent "Tide" as the polishing agent, sometimes adding a bit of jeweller's rouge or other polish as an extra.

The stones should be well covered with water in the container, and some filler should be added in the various steps to act as a buffer between the stones and as a carrier of the grinding grit. Two or three pounds of grit for 20 pounds of stone seems to work. If there is available a quantity of small fragments of hard quartzite, etc., it may be a good idea to put a few handfuls of this material in with the grit. It may assist in the grind- 
ing process, and you may sometime find a use for these small fragments when polished with the rest.

In constructing a tumbler it is desirable that provision be made whereby the gas generated in the tumbling process can be allowed to escape daily.

Experience will indicate the procedure that suits the individual. Experience will also indicate the types of rocks best suited for polishing. Generally, the harder the material, the better the polish. One soon learns to distinguish the harder types of rock. Among the rocks best adapted to polishing will be found petrified wood, agate and chalcedony and the harder of the fine grained quartzites, such as many of the banded quartzites found in the Cypress Hills and elsewhere.

For the person who has a quantity of rocks that are of little value for cutting with the diamond saw, the tumbler is very useful. Should the tumbling process show up specimens of especial interest; they can still be made other use of. Should there be a surplus of rocks too large for the tumbler, they can be broken up and also run through the machine. If only tumbling a small quantity of pieces, it might be advisable and desirable to rough-shape them prior to tumbling, especially if they are designed for jewellery use, such as lariat ties or other purposes. Cut slices may even be put through the tumbler with fair results, and save much hand polishing.

\section{THE BLUE JAY INDEX}

The Blue Jay Index, compiled by Mrs. Joyce Deutscher, S.IM.N.H., covers the first 18 years of the Blue Jay, from 1942 to 1960. Valuable for all who have complete or even partial sets of the Blue Jay; for those who want to check what records have been published before consulting sets owned by others; and for all those interested in the history and work of the Blue Jay. Price \$2.00 plus tax. Available from the Blue Jay, Box 1121, Regina, Sask.

Note that special publications \#1, 2 3 are also available at the above address.

\section{THE SASKATOON LAPIDARY AND MINERAL CLUB}

Back in March, 1961, a small group of interested people gathered in the Geology Department of the University of Saskatchewan. Under the able guidance of Ernie Hedger a club was organized and named the Saskatoon Lapidary and Mineral Society. Ernie Hedger was elected presidenit.

Since that time the membership has climbed to about fifty. Meetings are held at the University on the third Monday of each month excepting July and August. The Geology Department willingly contributes speakers whenever requested, which adds to the interest and educational value of these meetings.

Situated as we are on 3000 feet of glacial till does not make this exactly a rock hound's paradise, but it is surprising what can be found in the gravel pits. Wood is plentiful, usually as small, water-worn boulders. Jet black flint polishes beautifully and is not hard to find. Occasionally a real prize is picked up in the form of a bit of golden swirl agate, which equals California's finest.

Attendance on field trips continues to mount, and this winter should see more members "obtaining equipment and joining the "cutting fraternity."

Officers for 1962 are: Ernie Hedger, Past President; Dave Harrop, President; Tom Phenix, Vice-President; Ruby Drinkle (Mrs.), our able and hard working Secretary-Treasurer.

David Harrop, Saskatoon.

\section{REMINDER FROM THE BLUE JAY SHOP}

1. Now in Stock - Mrs. Alice Kehoe's Hunters of the buried years. Price, $\$ 2.00$ plus $10 \mathrm{c}$ tax.

2. Still Available-1962 Christmas Card (Downy Woodpecker). Price, $\$ 1.00$ plus 5c tax. 